\title{
Exploring Resources and Capabilities factors among Entrepreneurial Ventures using DEMATEL Approach
}

\author{
"Olamitunji Dakare ${ }^{1}$ \\ Sulaimon Olanrewaju Adebiyi \\ Bilqis Bolanle Amole ${ }^{3}$
}

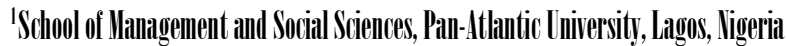

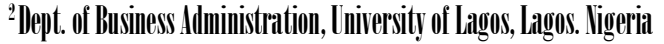

"Dept. of Lccounting/Business Idministrittion, Distince Learning Institute, Lniversity of Ligos, Ligeriit

\begin{abstract}
Resources and capabilities remain one of the most important factors that influence firms, more especially entrepreneurial ventures, to improve their competitiveness and achieve competitive advantage. In this context, present paper explores how entrepreneurial ventures and small businesses can better identify and distinguish the cause-and-effect relationship amongst resource and capability factors. Resource and capability factors among entrepreneurial ventures were classified into three dimensions and fourteen criteria after a review of the literature. The study applied the Decision-Making Trial and Evaluation Laboratory (DEMATEL) model to identify and describe the cause-and-effect relationship amongst resource and capability factors. The findings reveal that in prioritizing the importance of criteria and cause-and-effect relationship among criteria under the three core dimensions, firm climate, managerial competence, market knowledge and technological capabilities and equipment were the most critical criteria. Furthermore, the result has shown that firm climate is the most significant criterion in the adjustment of resource and capability factors of entrepreneurial ventures. Therefore, promoting a supportive and conducive firm climate among entrepreneurial ventures can enhance other resources and capabilities factors which, in turn, will improve the overall performance of entrepreneurial ventures and small businesses.
\end{abstract}

Keywords: Resources, capabilities, entrepreneurial ventures, small businesses, DEMATEL

JEL $: M 13$

Developed and developing nations have long recognized that entrepreneurial ventures and small businesses play a pivotal role in accelerating socio-economic development. However, the strategic tasks facing entrepreneurial ventures of all shapes and sizes have been how they can survive, gain and sustain competitive advantage with their limited set of distinctive resources and capabilities. According to Barney (1991), the strategic source of sustainable competitive advantage can only be derived from the resources and capabilities that an organisation or an entrepreneurial venture control.

More importantly, sustainable competition, through resources and capabilities, largely begin with 


\section{Dakare et al.}

organizational resources and capabilities that are valuable, rare, imperfectly imitable, and not substitutable (Barney, 1991; Barney, Wright and Ketchen, 2001). Also, resources and capabilities have been described and categorized as bundles of tangible and intangible assets (Barney et al., 2001; Hitt, Ireland and Hoskisson, 2003), while some scholars and managers have described a firm's resources and capabilities to include management skills, organizational processes and routines, as well as the information and knowledge that organizations control (Barney et al., 2001).

Today, most organizations, operating across the domestic, international and global fronts, are now leaning toward the use of their unique assets, owned and controlled as a key source of survival and sustainable competitive advantage (Barney and Clark, 2007). Also, as asserted by Barney et al. (2001), the dispersal of the resource-based view (RBV) in the field of strategic management and other associated disciplines has promoted the increasing interest of many academics and researchers to be involved in the theoretical development and empirical study of resources and capabilities (Andrews, 1971; Aaker, 1989; Barney, 1986; Barney, 1991; Conner, 1991; Collis and Montgomery, 1995; Day and Wensley, 1988; Day, 1994; Dierickx and Cool, 1989; Grant, 1991; Grant, 1996; Hansen and Wernerfelt, 1989; Lippman and Rumelt, 1982; Penrose, 1959; Prahalad and Hamel, 1990; Peteraf, 1993; Rumelt, 1984;; Rumelt, 1987; Rumelt , 1991; Spanos and Lioukas, 2001; Teece, Pisano and Shuen , 1997; Wernerfelt ,1984; Wernerfelt, 1989).

Therefore, in an attempt to achieve a clear and profound understanding of the contributions made from the extant studies on resources and capabilities, as an important source for organizations to develop and maintain competitive advantages, it suffices to say that, researchers in this discourse, have concentrated on three foremost streams of investigation:

I. Identification of resources and capabilities for sustainable competitive advantages (Amit and Schoemaker, 1993; Barney, 1991; Peteraf, 1993; Rumelt, Schendel and Teece, 1991; Wernerfelt, 1984).

II. Empirical studies that support the link between resources capabilities and various performance indicators (Alvarez and Barney, 2002; Barnett, Greve and Park, 1994; Barney and Arikan, 20- 
International Journal of Management, Economics and Social Sciences

01; Michael, Storey and Thomas, 2002; Mosakowski, 2002); and

III. Study of the antecedents of resources and capabilities or the variables that foster their development in organizations (Barney,1986; Rumelt,1984; Rumelt, 1987).

It is worth noting that the above-mentioned investigations have mainly considered resources and capabilities as the essential components, needed by organizations to survive and sustain competitive advantage (Barney and Clark, 2007). However, these previous studies on resources and capabilities, as determinants for organizations' competitive advantage, have some limitations. First, several studies have presumed that the resources and capabilities factors are independent of one another and are not causally related. Second, most studies have also presumed that the weights of the evaluated factors are identical. In order to overcome limitations highlighted above and to answer the following research questions that arose from the foregoing analysis - "What are the resources and capabilities factors related to entrepreneurial venture or small business in sustaining and creating competitive advantage?" and "Which resources and capabilities factors are the most influential factors in sustaining competitive advantage among entrepreneurial ventures?, this study employs the DEMATEL (Decision Making Trial and Evaluation Laboratory) method.

This study, however, reflects a mixture of the three research inclinations by extending the line of inquiry to determine how organizations, more especially entrepreneurial ventures and small businesses, can better identify and distinguish the cause-and-effect relationship amongst resources and capabilities factors. None of these previous investigations had directly tested multiple criteria decisionmaking (MCDM) methods in handling several complex factors that determine how to identify the specific resources and capabilities required for expected outcomes of business purposes (Wu, 2008). That is the research gap which this study is motivated to fill. Another potential contribution of this study is the use of the technique Decision Making Trial and Evaluation Laboratory (DEMATEL), which will, hopefully, provide a better understanding of how these distinct sets of resources and capabilities of 


\section{Dakare et al.}

entrepreneurial ventures and small businesses affect each other and their final success.

For the purpose of achieving its aims, this article is divided into four sections. The first section provides a picture of the existing literature and the theoretical background related to the study. The second section addresses the research methods used in the study. The third section presents the results and discussions. Finally, the fourth section provides the concluding comments.

\section{LITERATURE REVIEW}

\section{The Resource-Based View (RBV) Perspective}

The extensive studies and discussions of resources and capabilities in the field of strategic management and entrepreneurship cannot be overemphasised, while the definition of the concept "resources and capabilities" not only remains to be properly verified but has also evolved along with abundant researches. For instance, the perception from early research studies referred to resources and capabilities as bundles of tangible and intangible assets, which include a firm's management skills, its organisational processes and routines, and the information and knowledge it controls (Barney, 1991; 2001 et al.) for the purpose of generating sustainable competitive advantage and earning above-normal rates of return (Barney, 1991; Wernerfelt, 1984). The overall assumption of RBV is that a firm can sustain and create competitive advantage through its bundles of resources and capabilities, rather than through how it positions itself in the market. With this assertion, the RBV is able to justify the dissimilarities in firm performance, not expounded by industry factors (Ortega, 2010). The widespread discussions in the 1990s have, however, further expressed the relationship between resources and capabilities. More specifically, Grant (1991), and Amit and Schoemaker (1993) have strongly argued that resources are inputs with which an organisation intends to carry out its activities. According to Grant (1991), resources alone do not generate any rent or secure advantages on the competitors, it is the capabilities that indeed provide the knack to manage aptly the resources to carry out a certain activity within an organisation (Grant, 1991). A capability is, therefore, a form in which an organisation combines its resources (Amit and Schoemaker, 1993) for the purpose of improving the productivity of other resources possessed by the firm (Makadok, 2001). 
International Journal of Management, Economics and Social Sciences

These upward research trends reflect that resources and capabilities can only ensure sustainable competitive advantage, if they are valuable (Barney and Arikan, 2001), rare, inimitable and organised (Barney and Hesterly, 2012). Researches have also summarised the components of resources and capabilities to include organisational resources and capabilities (Teece et al., 1997), marketing resources and capabilities (Lado, Boyd and Wright, 1992) and technical resources and capabilities (Leonard-Barton, 1995; Lado et al., 1992). Thus, resources and capabilities are key success factors for organisations to survive in a changing environment.

Despite the fact that RBV has been criticised on the ground that this school of thought has mainly concentrated on the perspective's internal focus and lacks dynamics (Foss, 1998), these criticisms have gradually been mitigated (Boccardelli and Magnusson, 2006). For instance, Amit and Schoemaker (1993) provided a connection between the internal resources and capabilities of the firm and the competitive situation at the industry level. Furthermore, Teece et al. (1997) added dynamics to the perspective by presenting the dynamic capabilities framework, based on the notions of position, process, and paths. The above arguments for the resource-based view school have extended its applicability domain to more rapidly developing and highly competitive environments (Boccardelli and Magnusson, 2006).

\section{Defining Resources and Capabilities for a Successful Entrepreneurial Venture and Small Business}

The relevant question is: "What are the resources and capabilities factors related to entrepreneurial venture or small business in sustaining and creating competitive advantage?" In response to this question, Ritam and Kalyan (2014) maintain that, for small businesses and entrepreneurial ventures to sustain and create competitive advantage through their resources and capabilities, they need to align their specific strengths with their expertise, to be able to increase their alliance capability. For Hashai and Almor (2004), and Knight and Cavusgil (2004), unique technologies and innovation factors are significant determinants of sustainable competitive advantage, superior capability to perform R\&D activities (Knight and Cavusgil, 2004; Manalova, 2003), network partnerships that provide social capital (Davidson and Honig, 2003), brand names, in-house knowledge of technology, skilled 


\section{Dakare et al.}

personnel, trade contracts, ef ficient procedures, fi nancial, reputational (Spanos and Lioukas, 2001). However, with regard to the effects of resources and capabilities on firm performance, empirical results are mixed (Hitt, Hoskisson and Kim, 1997). In addition, Parayitam and Guru-Gharana (2010) and Radulovich (2008) take the view that researchers have a restricted understanding of firm performance and sustainable competitive advantage benefits of resources and capabilities. Based on the foregoing findings, this paper further applies the focus group research method to define specific resources and capabilities factors for entrepreneurial ventures and small businesses.

According to Lin et al. (2011), the purpose of focus group research is to facilitate an organised selected group discussion, which includes representatives of various classes. While the outcomes of these discussions give insights and also provide a better understanding of the subject, which simple survey items may not be able to achieve (Lin et al., 2011). Furthermore, focus group discussions allow brainstorming that brings additional information to the current issues and stimuli for new ideas. The present study has, however, raised a number of issues, including the possible resources and capabilities factors that are recognised by entrepreneurs' experts and academics. Through the focus group research procedure, based on the current studies of resources and capabilities, three resource and capabilities factors (i.e., organizational/managerial capabilities, marketing capabilities and technical capabilities), which are in line with the empirical research findings of Lado et al. (1992), Leonard-Barton (1995), Spanos and Lioukas (2001), and Teece et al., (1997), present study uses

discussions that are aided with answers to open-ended questionnaires and recording equipment; opinions, however, are integrated and summarised. These will be analysed and discussed in the next session of study. Consequently, in this present study, the resources and capabilities factors, related to entrepreneurial venture or small business in sustaining and creating competitive advantage, include measures of organizational, marketing and technical capabilities factors.

\section{METHODOLOGY}

First, the expert validity survey has been used for this study. This research design helps to gather experts to confirm their expertise in an area or field (Lin et al., 2011). Based on this design, a panel of 
International Journal of Management, Economics and Social Sciences

qualified expert entrepreneurs was formed as a focus group and in-depth discussions, to gauge more specific ideas about resources and capabilities, were carried out. Thus, this group of experts provided their suggestions and reviews, based on their expertise and previous studies in literature that the authors have reviewed. Consequently, the substantial outlooks received from the discussions provided justifications for the results and helped to answer the research question: "What are the resources and capabilities factors related to entrepreneurial venture or small business in sustaining and creating competitive advantage?" During the course of the literature reviews and the process of the focus group, three resource and capabilities factors were identified. They are: organizational/managerial capabilities, marketing capabilities and technical capabilities factors (see Table 1, Appendix-I). Finally, the DEMATEL approach was employed to answer the research question: "Which resources and capabilities factors are the most influential factors in sustaining competitive advantage among entrepreneurial ventures?"

As noted earlier in this paper, DEMATEL is the acronym for Decision Making Trial and Evaluation Laboratory, as advanced by the Battle Memorial Institute, Geneva. According to Lin et al. (2011), the DEMATEL technique was originally designed for the purpose of explaining and understanding structural relations in a complex system. For Zhou, Huang and Zhang (2011), it helps to analyze complex problems related to real life. Ashtianipouri and Zandhessame (2015) maintain that it is a technique used to elicit expert opinions in order to have a clear view of a contextual relationship that exists among variables.

Meanwhile, much of the prolific academic researchers in many fields (e.g., Wu, 2008; Lin et al., 2011; Zhou et al., 2011; Ashtianipouri and Zandhessame, 2015; Raghuvanshi, Agrawal, and Ghosh, 2017) have reaffirmed that DEMATEL, as a technique, is useful when it comes to causal analysis because it enables studies to distinguish the connecting criteria of a system into cause and effect groups. DEMATEL, as pointed out by Lin et al. (2011), allows decision-makers to recognise criteria that are of greater effect. Consequently, this study has adopted the DEMATEL approach since it can solve the causal relationship issues of resources and capabilities, required for expected outcomes of an 


\section{Dakare et al.}

entrepreneurial venture, which, in turn, provides progressive options. The DEMATEL model construction process is stated below:

Step 1: Generating the direct relationship matrix: To draw the inter-relationships among various variables, a group of subject-related experts was formed that included four experts, two of whom were professors of entrepreneurship and two entrepreneurship experts, were requested to form a pair-wise matrix of variables, using the five-point scale to measure their responses (' 0 ' indicates 'no influence', '1' indicates 'Iow influence', '2' indicates 'medium influence', '3' indicates 'high influence', '4' indicates 'extremely influence').

Step 2: Computing the average relation matrix: The average relationship was determined by calculating four direct relationship matrices X1, X2, X3, X4, from Equation 1

$$
\mathrm{A}=\frac{I}{K}\left(X_{1}+X_{2}+X_{3}+X_{4}\right) \text { where } \mathrm{K} \text {-expert }=4(\text { see Table 2, Appendix-II) }
$$

Step 3: Computing the normalised direct relationship matrix (N): Through Equations (2) and (3) the normalised matrix $(\mathrm{N})$ was obtained.

$$
\mathrm{a}=\operatorname{Min}\left\{\frac{1}{\max \Sigma_{i}^{n} A}, \frac{1}{\max \Sigma_{j}^{n} A}\right\}
$$

Hence, $a=0.057$ (see Table 3, Appendix-III)

$$
\mathrm{N}=a * A \quad(3)
$$

Note: a represents constant, while $A$ is referred to as the element of the average relationship matrix, the ' $i$ represents an element of row and ' $j$ ' represents an element of the column.

Step 4: Constructing the total-relation matrix: First, the normalized matrix was obtained and thereafter the total relationship matrix was calculated by

$$
\mathrm{T}=\left(N(I-N)^{-1}\right)
$$

The "/", however, symbolizes identity matrix. (see Table 4, Appendix-IV)

Step 5: Calculating the cause-and-effect relationship: Through Equations (5) and (6) the cause-andeffect relationship Table was determined.

The "R" means the sum of rows, while "C" means the sum of columns. 
International Journal of Management, Economics and Social Sciences

$$
\begin{aligned}
& R=\left(\sum_{j=1}^{n} T_{i j}\right)_{n x 1} \\
& C=\left(\sum_{i=1}^{n} T_{i j}\right)_{1 x n}
\end{aligned}
$$

\section{Study Questionnaire}

The study questionnaire was adapted from Spanos and Lioukas (2001) comprised of three dimensions (i.e., organizational/managerial, marketing and technical capabilities) and 60 items, A five-point Likert scale was used to tap responses. This research instrument was, however, modified, based on the substantial viewpoints received from the focus group discussions, as earlier explained in this study. Consequently, the research instrument was subjected to validity testing through theoretical validity, nomological validity and content validity.

\section{DISCUSSION}

For this study to identify and distinguish the cause-and-effect relationship amongst the distinctive sets of resources and capabilities of entrepreneurial ventures and small businesses, the threshold value (0.181) was set-up to sort out or rank the insignificant effects. The measures/criteria were ranked according to importance or influence on the basis of $(R+C)$ values, as follows: $F C>M C>E O S>C O R$

$>\mathrm{KSE}>\mathrm{ACE}>\mathrm{SP}>\mathrm{CIB}>\mathrm{MK}>\mathrm{ARC}>\mathrm{CDC}>\mathrm{TCE}>\mathrm{EPD}>\mathrm{EST}$.

$(\mathrm{R}-\mathrm{C})$ values are used to rank causal resources and capabilities factors amongst entrepreneurial ventures and small businesses, which are as follows: $A C E>M C>K S E>F C>E O S>M K>E P D>$ $\mathrm{TCE}>\mathrm{ARC}>\mathrm{CIB}>\mathrm{CDC}>\mathrm{EST}>\mathrm{COR}>\mathrm{SP}$.

Setting a Threshold value $(\alpha)$ :

$$
\frac{35.42}{196}=0.181
$$

According to Table 5 (see Appendix-V), under organizational capabilities measures, this study found that firm climate and managerial competence were the two most important criteria, based on first and second highest $(R+C)$ values of 10.026 and 9.253 , respectively, whereas both firm climate and managerial competence were in the cause group, based on their positive $(R-C)$ values of 0.815 and 0.524 , respectively. Strategic planning and coordination were in the effect group, given negative $(\mathrm{R}-\mathrm{C})$ 


\section{Dakare et al.}

values of -1.949 and -1.387 , respectively. Also, considering the figures obtained in Table 5 , firm climate emerged the most critical distinctive set of organizational/managerial resources and capabilities factors. This is because it has a direct influence on the other six criteria. This finding is in alignment with that of Hult et al. (2007), they conclude that a culture of competitiveness [or firm climate], and knowledge development, including their interaction, increase performance. Meanwhile, managerial competence has a direct impact on strategic planning and a mutual interaction on coordination. This finding is also supported by Hooley et al. (2005) strongly argue that managerial competence upsurge reputational assets, organization reputation, brand, and credibility are significant assets in increasing firm performance.

Furthermore, the results in Table 5 also show that, for marketing capabilities measures amongst entrepreneurial ventures, the customers' "installed base" and market knowledge were the two most important criteria, based on higher $(\mathrm{R}+\mathrm{C})$ values of 1.407 and 1.388 , respectively. The customers' "installed base" shows a negative net cause of $(R-C)$ value of -0.023 , while the market knowledge shows a positive net cause of $(\mathrm{R}-\mathrm{C})$ value of 0.086 . Control and access to distribution channels has a net cause of $(R-C)$ value of -0.065 . Consequently, the figure obtained in Table 5 depicts market knowledge as the most significant distinctive set of marketing capabilities factor, since it has a significant impact on the other three criteria. This finding is also supported by the study carried out by Hult and Ketchen (2001); Menguc and Auh (2006); and Hult et al. (2005). These studies maintain that market orientation and market information processing have a strong impact on firm performance.

For the technical capabilities' measures, technological capabilities and equipment factor is the most important criterion, as it provides the highest $(R+C)$ value of 0.898 . This finding is also supported by the studies carried out by Ashtianipour and Zandhessami (2015) and Ortega, (2010), which maintained that entrepreneurs' utilization of technological capabilities will not only improve competitiveness but also lead to achieving competitive advantage. Efficient and effective production department is next to it, with an $(R+C)$ value of 0.878 . However, based on the $(R-C)$ value of 0.054 , efficient and effective production department was found to be the net cause and has a significant impact on the 
other two criteria. This finding is also supported by the study conducted by Lages et al. (2009) that emphasizes that organizational learning capability improves product innovation.

\section{CONCLUSION}

This study has explored how entrepreneurial ventures and small businesses can better identify and distinguish cause-and-effect relationship amongst resources and capabilities factors. Resources and capabilities remain one of the most important factors that influence firms, more especially entrepreneurial ventures, to improve their competitiveness and achieve competitive advantage. Although, previous studies had focused mostly on understanding the resources and capabilities of an industry or a firm, they had not provided enough analysis on the interaction relation among them.

Consequently, our study applied the DEMATEL method to identify and describe the cause-andeffect relationship amongst the resource and capabilities factors of entrepreneurial ventures, which were classified into three dimensions and fourteen criteria after a review of the literature. The result of the study implied that entrepreneurs and their management should focus on how they will continue to improve their firms' organizational capabilities in the cause group (i.e., firm climate and managerial competence). The findings reveal that, in prioritizing the importance of criteria and cause-and-effect relationship among criteria under the three core dimensions, firm climate, managerial competence, market knowledge and technological capabilities and equipment were the most critical criteria. Furthermore, the result shows that a firm's climate is the most significant criterion in the adjustment of resource and capability factors of entrepreneurial ventures. Therefore, promoting a supportive and conducive firm climate among the entrepreneurial ventures can enhance other resources and capabilities factors, which, in turn, will improve the overall performance of entrepreneurial ventures and small businesses.

\section{IMPLICATIONS}

The results of this study have shown that there is in fact strong and positive evidence that resources and capabilities remain one of the most important factors that influence entrepreneurial ventures and small businesses to improve their competitiveness and achieve competitive advantage. 


\section{Dakare et al.}

In terms of theoretical implications, firm climate, among other criteria in the adjustment of resources and capabilities dimensions, serves as the "ultimate" sources of sustainable competitive advantage among entrepreneurial ventures and small businesses. This result is in line with those of previous research studies (e.g., Hult et al., 2007, and Lages et al., 2009). The findings also provide a useful guide to entrepreneurial managers and practitioners on the need to create and promote a supportive as well as conducive firm climate that will enhance other resource and capability factors, which, in turn, will improve the overall competitiveness of entrepreneurial ventures and small businesses. The findings show clearly that, when considering resources and capabilities decisions under the three core dimensions, more focus needs to be given to firm climate, managerial competence, market knowledge, technological capabilities and equipment. This result, therefore, provides a clue as to why most of the small businesses and entrepreneurial ventures usually first try to create a supporting firm climate in line with their managerial aptitudes, which have also helped them to develop capacity building programs, which, in turn, have improved their workforce. As pointed out by Hewitt and Wield (1992), and Lucas (1993), a workforce that is knowledgeable and cultured is likely to be more efficient because of their greater ability to engross and effectively utilize new technology.

From the practice point of view, the results further reinforce the view that entrepreneurial ventures and small businesses need to identify and prioritize resources and capabilities when the environment is in a state of turmoil, since resources and capabilities factors within a business become more of a stable factor on which small businesses can base their competitive advantage. Consequently, when managers of small businesses are accessing their bundle of resources and capabilities in order to achieve a sustainable competitive advantage, it is important to consider the relative importance of criteria within each dimension of resource and capabilities factors. For example, firm climate and managerial competence are the most critical criteria within the organizational/managerial dimension of resources and capabilities factors. The ideal practice for entrepreneurial ventures and small businesses is to concentrate on how they can manage all three dimensions of resources and capabilities factors in order to enhance their business performance optimally and sustain their competitive advantage. 
International Journal of Management, Economics and Social Sciences

\section{LIMITATIONS AND FUTURE DIRECTIONS}

Our study has some limitations. First, the proposed DEMATEL method in this study is designed to solve the determination of a complex and interactive resources and capabilities issue of an entrepreneurial venture and small business. Further, research would need to provide an elaborate analysis of other sub-sectors of entrepreneurial ventures and small businesses. Second, this study was carried out by only employing the opinions of four experts; further research could be conducted by employing more robust statistical techniques in order to get more valid results. We also suggest that, in carrying out further research in the various sectors of small businesses and entrepreneurial ventures, there is need to employ other multi-criteria decision-making methods, such as the Analytical Hierarchy Process (AHP), Technique for Order Preference by Similarity to an Ideal Solution (TOPSIS), and Interpretive Structural Modeling (ISM), for the purpose of comparative analysis.

\section{REFERENCES}

Aaker, D. A. (1989). Managing assets and skills: The key to a sustainable competitive advantage. California Management Review, 31(2): 91-106.

Alvarez, S. A., \& Barney, J. B. (2002). Resource-based theory and the entrepreneurial firm. In M. A. Hitt, R. D. Ireland, S. M. Camp, \& D. L. Sexton (Eds.), Strategic entrepreneurship: Creating a new mindset: 89-105. Oxford: Blackwell Publishers

Amit, R. \& Schoemaker, P. J. (1993). Strategic assets and Organizational rent. Strategic Management Journal, $13,33-46$.

Andrews, K. R. (1971). The concept of corporate strategy. Irwin: Homewood, IL.

Ashtianipour, Z. \& Zandhessami, H. (2015). An integrated ISM-DEMATEL model for evaluation of technological innovation capabilities' impact on the competitiveness of small \& medium size enterprises (SMEs). Proceedings of PIC MET '15: Management of the Technology Age, 322-334.

Barnett, W. P., Greve, H. R., \& Park, D. Y. (1994). An evolutionary model of organizational performance. Strategic Management Journal, 15 (Special Issue): 11-28.

Barney, J. B. (1986). Strategic factor markets: Expectations, luck, and business strategy. Management Science, 32(10): 12311242.

Barney, J. B. (1991). Firm resources and sustained competitive advantage. Journal of Management, 17(1): 99-121.

Barney, J. B., \& Arikan, A. M. (2001). The resource-based view: Origins and implications. In M. A. Hitt, R. F. Freeman, \& J. S. Harrison (Eds.), Handbook of strategic management. 124-188. Oxford: Blackwell Publishers.

Barney, J.B. \& Clark, D.N. (2007). Resource-based theory Creating sustaining competitive advantage. New York: Oxford University Press.

Barney, J., \& Hesterly, W. (2012). Strategic management and competitive advantage: Concepts and cases (4th ed.). New Jersey: Pearson.

Barney, J. B., Wright, M., \& Ketchen, D. J. (2001). The resource-based view of the firm: Ten years after 1991. Journal of Management, 27(6): 625-641.

Boccardelli, P. and Magnusson, M. G. (2006). Dynamic capabilities in early-phase entrepreneurship. Knowledge and Process Management, 14(3): 162-174.

Collis, D. J. \& Montgomery, C. A. (1995). Competing on resources: Strategy in the 1990s. Harvard Business Review, 118-128.

Conner, K. (1991). Historical comparison of resource-based theory and five schools of thought within industrial organization economics: Do we have a new theory of the firm?. Journal of Management, 17(1): 121-154.

Davidson, P.P. \& Honig, B. (2003). The role of social and human capital among nascent entrepreneurs. Journal of Business Venturing, 18, 301-331.

Day, G. S. \& Wensley, R. (1988). Assessing advantage: A framework for diagnosing competitive superiority. Journal of Marketing, 52, 1-20.

Day, G. S. (1994). The capabilities of market-driven organizations. Journal of Marketing, 58(4): 37-52.

Dierickx, I., \& Cool, K. (1989). Asset stock accumulation and sustainability of competitive advantage. Management Science, 32(12): 1504-1512. 


\section{Dakare et al.}

Foss, N. (1998). The resource-based perspective: An assessment and diagnosis of problems. Scandinavian Journal of Management, 14(3): 133-149.

Grant, R. M. (1991). The resource-based theory of competitive advantage: Implications for strategy formulation. California Management Review, Spring, 114-135.

Grant, R. M. (1996). Toward a knowledge-based theory of the firm. Strategic Management Journal, 17, 109-122.

Hamel, G. \& Prahalad, C. (1996). Competing for the Future. Boston (Massachusetts): Harvard Business School Press.

Hansen, G. S. \& Wernerfelt, B. (1989). Determinants of firm performance: The relative importance of economic and organizational factors. Strategic Management Journal, 10, 399-411.

Hashai, N. \& Almor, T. (2004). Gradually internationalizing 'born global' firms: an oxymoron? International Business Review, 13(4): 465-483.

Hewitt T, Wield D (1992). Technology and industrialization, in T. Hewitt, H. Johnson and D. Wield, (eds.), Industrialization and development, Oxford University Press.

Hitt, M.A., Ireland, D.R., \& Hoskisson, R.E. (2003). Strategic management: competitiveness and globalization (5th Edition). United States: Thomson South-Western.

Hitt, M.A., Hoskisson, R.E. \& Kim, H. (1997). International diversification: Effects on innovation and firm performance in product-diversified firms. Academy of Management Journal, 40(4): 767-798.

Hooley, G., Greenley, G., Fahy, J., \& Cadogan, J. (2005). Market focused resources, competitive positioning and firm performance. Journal of Marketing Management, 17(5/6): 503-520.

Hult, G. T. M., \& Ketchen, D. J. (2001). Does market orientation matter? A test of the relationship between positional advantage and performance. Strategic Management Journal, 22(9): 899- 906.

Hult, G. T. M., Ketchen, D. J., \& Slater, S. F. (2005). Market orientation and performance: An integration of disparate approaches. Strategic Management Journal, 26(12): 1173-1181.

Hult, G. T. M., Ketchen, D. J., \& Arrfelt, M. (2007). Strategic supply chain management: Improving performance through a culture of competitiveness and knowledge development. Strategic Management Journal, 28(10): 1035-1052.

Knight, G. \& Cavusgil, T. (2004). Innovation, organizational capabilities, and the born global firm. Journal of International Business Studies, 35(2): 124-141.

Lado, A., Boyd, N., \& Wright P. (1992). A competency-based model of sustainable competitive advantage: toward a conceptual integration. Journal of Management, 18, 77-91.

Lages, L. F., Silva, G., \& Styles, C. (2009). Relationship capabilities, quality, and innovation as determinants of export performance. Journal of International Marketing, 17(4): 47-70.

Leonard-Barton D. (1995). Wellsprings of knowledge: Building and sustaining the sources of innovation. Boston: Harvard Business School Press.

Lin, Y.T., Yang, Y.H., Kang, J.S., \& Yu, H.C. (2011). Using DAMATEL method to explore the core competences and causal effect of the IC design service company: An empirical case study. Expert System with Applications, 38, 6262-6268.

Lippman, S. and Rumelt, R. P. (1982). Uncertain imitability: An analysis of inter-firm differences in efficiency under competition. Bell Journal of Economics, 13, 418-438.

Lucas, R. (1993). Making of a miracle. Econometrics, 61, 251-272.

Michael, S., Storey, D., \& Thomas, H. (2002). Discovery and coordination in strategic management and entrepreneurship. In M. A. Hitt, R. D. Ireland, S. M. Camp, \& D. L. Sexton (Eds.), Strategic entrepreneurship: Creating a new mindset: 45-65. Oxford: Blackwell Publishers.

Makadok, R. (2001). Toward a synthesis of the resource-based and dynamic-capability views of rent creation. Strategic Management Journal, 22(5): 387-401.

Manalova, T.S. (2003). Small multinationals in global competition: an industry perspective, In: H. Etemad and R. Wright (eds.) Globalization and entrepreneurship: policy and strategy perspectives. Cheltenham, UK: Edward Elgar Publishing Limited.

Menguc, B., \& Auh, S. (2006). Creating a firm-level dynamic capability through capitalizing on market orientation and innovativeness. Journal of the Academy of Marketing Science, 34(1): 63-73.

Mosakowski, E. (2002). Overcoming resource disadvantages in entrepreneurial firms: When less is more. In M. A. Hitt, R. D. Ireland, S. M. Camp, \& D. L. Sexton (Eds.), Strategic entrepreneurship: Creating a new mindset: 106-126. Oxford: Blackwell Publishers.

Ortega, M.J.R. (2010). Competitive strategies and firm performance: Technological capabilities moderating roles. Journal of Business Research, 63, 273-1281.

Parayitam, S. \& Guru-Gharana, K. (2010). Economics of resource based and dynamic capabilities view: A contemporary framework. Academy of Strategic Management Journal, 9(1): 83-93.

Penrose, E. T. (1959). The theory of the growth of the firm. Oxford: Oxford University.

Peteraf, M. A. (1993). The cornerstones of competitive advantage: A resource-based view. Strategic Management Journal, 14 , 179-191.

Prahalad, C. \& Hamel, G. (1990). The core competence of the corporation. Harvard Business Review, 68(3): 79-91.

Radulovich, L.P. (2008). An empirical examination of the factors affecting internationalization of professional service SMEs: The case of India. Dissertation, Cleveland State University.

Raghuvanshi, J., Agrawal, R., \& Ghosh, P.K. (2017). Analysis of barriers to women entrepreneurship: The DEMATEL approach. The Journal of Entrepreneurship, 26(2): 220-238.

Ritam, G. \& Kalyan, K. D. (2014). An exposition of resources capabilities for SMEs in the emerging markets. SAJEMS 17(3), 310-318.

Rumelt, R. P. (1984). Towards a strategic theory of the firm, In R. B. Lam (Ed.), Competitive Strategic Management. Englewood Cliffs, NJ: Prentice Hall.

Rumelt, R. P. (1987). Theory, strategy and entrepreneurship, In D. J. Teece (Ed.), The competitive challenge. New York: Harper \& Row. 
International Journal of Management, Economics and Social Sciences

Rumelt, R. P. (1991). How much does industry matter? Strategic Management Journal, 12(3): 167-185.

Rumelt, R. P., Schendel, D., \& Teece, D. J. (1991). Strategic management and Economics. Strategic Management Journal, 12, 5-30.

Spanos, Y. E. and Lioukas, S. (2001). An examination into the causal logic of rent generation: Contrasting Porter's competitive strategy framework and the resource-based perspective. Strategic Management Journal, 22, 907-934.

Teece, D. J., Pisano, G., \& Shuen, A. (1997). Dynamic capabilities and strategic Management. Strategic Management Journal, 18(7): 509-534.

Wernerfelt, B. (1984). A resource-based view of the firm. Strategic Management Journal, 5, 171-180.

Wernerfelt, N. (1989). From critical resources to corporate strategy. Journal of General Management, 14, 4-12.

Wu, W.W. (2008). Choosing knowledge management strategies by using a combined ANP and DEMATEL approach. Expert Systems with Applications 35, 828-835.

Zhou, Q., Huang, W., \& Zhang, Y. (2011). Identifying critical success factors in emergency management using a fuzzy DEMATEL method. Safety Science, 49(2): 243-252. 


\begin{tabular}{cc}
\hline Code & Measures \\
\hline 1. & Organizational/Managerial Capabilities \\
MC & Managerial competence \\
KSE & Knowledge and skills of employees \\
FC & Firm climate \\
EOS & Efficient organizational structure \\
COR & Coordination \\
SP & Strategic planning \\
ACE & Ability to attract creative employees \\
\hline $\mathbf{2 .}$ & Marketing Capabilities \\
MK & Market knowledge \\
CDC & Control and access to distribution channels \\
ARC & Advantageous relationships with customers \\
CIB & Customers "installed base" \\
\hline 3. & Technical Capabilities \\
EPD & Efficient and effective production department \\
EOS & Economies of scales and technical experience \\
TCE & Technological capabilities and equipment \\
\hline Source: Authors' own
\end{tabular}

Table 1. Measures of Resources and Capabilities 
Appendix-II

\begin{tabular}{ccccccccccccccc}
\hline & MC & KSC & FC & EOS & COR & SP & ACE & MK & CDC & ARC & CIB & EPD & EST & TCE \\
\hline MC & 0 & 3 & 3 & 2.25 & 2.25 & 3.5 & 2.5 & 0 & 0 & 0 & 0 & 0 & 0 & 0 \\
KSC & 2.5 & 0 & 3.25 & 3 & 3 & 1.5 & 1.5 & 0 & 0 & 0 & 0 & 0 & 0 & 0 \\
FC & 2.25 & 3 & 0 & 2.75 & 3.25 & 3.25 & 3 & 0 & 0 & 0 & 0 & 0 & 0 & 0 \\
EOS & 2.5 & 2.5 & 2.5 & 0 & 2.75 & 2.25 & 2.25 & 0 & 0 & 0 & 0 & 0 & 0 & 0 \\
COR & 1.75 & 1.25 & 2.5 & 1.75 & 0 & 3 & 2.25 & 0 & 0 & 0 & 0 & 0 & 0 & 0 \\
SP & 2.5 & 1 & 2 & 1.5 & 2.75 & 0 & 1.25 & 0 & 0 & 0 & 0 & 0 & 0 & 0 \\
ACE & 2.25 & 2 & 2.5 & 2.75 & 3 & 2.75 & 0 & 0 & 0 & 0 & 0 & 0 & 0 & 0 \\
MK & 0 & 0 & 0 & 0 & 0 & 0 & 0 & 0 & 2.5 & 2.75 & 2.75 & 0 & 0 & 0 \\
CDC & 0 & 0 & 0 & 0 & 0 & 0 & 0 & 2.25 & 0 & 2 & 2.25 & 0 & 0 & 0 \\
ARC & 0 & 0 & 0 & 0 & 0 & 0 & 0 & 2.5 & 2.75 & 0 & 2.5 & 0 & 0 & 0 \\
CIB & 0 & 0 & 0 & 0 & 0 & 0 & 0 & 2.5 & 2.75 & 2.5 & 0 & 0 & 0 & 0 \\
EPD & 0 & 0 & 0 & 0 & 0 & 0 & 0 & 0 & 0 & 0 & 0 & 0 & 3 & 2.75 \\
EST & 0 & 0 & 0 & 0 & 0 & 0 & 0 & 0 & 0 & 0 & 0 & 2 & 0 & 2.5 \\
TCE & 0 & 0 & 0 & 0 & 0 & 0 & 0 & 0 & 0 & 0 & 0 & 3 & 2.75 & 0 \\
\hline Source: Authors' own & & & & & & & & & & & &
\end{tabular}

Source: Authors' own

Table 2. Direct-Influence Matrix 
Dakare et al.

Appendix-III

\begin{tabular}{ccccccccccccccc}
\hline & MC & KSC & FC & EOS & COR & SP & ACE & MK & CDC & ARC & CIB & EPD & EST & TCE \\
\hline MC & 0 & .171 & .171 & .128 & .128 & .199 & .143 & 0 & 0 & 0 & 0 & 0 & 0 & 0 \\
KSC & .143 & 0 & .185 & .171 & .171 & .086 & .086 & 0 & 0 & 0 & 0 & 0 & 0 & 0 \\
FC & .128 & .171 & 0 & .157 & .185 & .185 & .171 & 0 & 0 & 0 & 0 & 0 & 0 & 0 \\
EOS & .143 & .143 & .143 & 0 & .157 & .143 & .143 & 0 & 0 & 0 & 0 & 0 & 0 & 0 \\
COR & .099 & .071 & .128 & .099 & 0 & .171 & .128 & 0 & 0 & 0 & 0 & 0 & 0 & 0 \\
SP & .128 & .057 & .114 & .086 & .157 & 0 & .017 & 0 & 0 & 0 & 0 & 0 & 0 & 0 \\
ACE & .128 & .114 & .143 & .157 & .171 & .157 & 0 & 0 & 0 & 0 & 0 & 0 & 0 & 0 \\
MK & 0 & 0 & 0 & 0 & 0 & 0 & 0 & 0 & .128 & .157 & .157 & 0 & 0 & 0 \\
CDC & 0 & 0 & 0 & 0 & 0 & 0 & 0 & .128 & 0 & .114 & .128 & 0 & 0 & 0 \\
ARC & 0 & 0 & 0 & 0 & 0 & 0 & 0 & .128 & .128 & 0 & .143 & 0 & 0 & 0 \\
CIB & 0 & 0 & 0 & 0 & 0 & 0 & 0 & .128 & .157 & .128 & 0 & 0 & 0 & 0 \\
EPD & 0 & 0 & 0 & 0 & 0 & 0 & 0 & 0 & 0 & 0 & 0 & 0 & .171 & .157 \\
EST & 0 & 0 & 0 & 0 & 0 & 0 & 0 & 0 & 0 & 0 & 0 & .114 & 0 & .143 \\
TCE & 0 & 0 & 0 & 0 & 0 & 0 & 0 & 0 & 0 & 0 & 0 & .171 & .157 & 0 \\
\hline Source: Authors' own & & & & & & & & & & & & & &
\end{tabular}

Table 3. Direct-Relation Matrix 


\begin{tabular}{|c|c|c|c|c|c|c|c|c|c|c|c|c|c|c|}
\hline & MC & KSC & FC & EOS & COR & SP & ACE & MK & CDC & ARC & CIB & EPD & EST & TCE \\
\hline MC & 0.569 & 0.681 & 0.786 & 0.695 & 0.814 & 0.854 & 0.635 & 0 & 0 & 0 & 0 & 0 & 0 & 0 \\
\hline KSC & 0.653 & 0.5 & 0.752 & 0.688 & 0.797 & 0.721 & 0.564 & 0 & 0 & 0 & 0 & 0 & 0 & 0 \\
\hline FC & 0.708 & 0.704 & 0.669 & 0.744 & 0.891 & 0.876 & 0.683 & 0 & 0 & 0 & 0 & 0 & 0 & 0 \\
\hline EOS & 0.659 & 0.628 & 0.727 & 0.546 & 0.794 & 0.772 & 0.609 & 0 & 0 & 0 & 0 & 0 & 0 & 0 \\
\hline COR & 0.52 & 0.47 & 0.595 & 0.528 & 0.53 & 0.669 & 0.499 & 0 & 0 & 0 & 0 & 0 & 0 & 0 \\
\hline SP & 0.468 & 0.391 & 0.502 & 0.44 & 0.573 & 0.435 & 0.347 & 0 & 0 & 0 & 0 & 0 & 0 & 0 \\
\hline ACE & 0.642 & 0.599 & 0.72 & 0.676 & 0.799 & 0.778 & 0.479 & 0 & 0 & 0 & 0 & 0 & 0 & 0 \\
\hline MK & 0 & 0 & 0 & 0 & 0 & 0 & 0 & 0.084 & 0.203 & 0.222 & 0.228 & 0 & 0 & 0 \\
\hline CDC & 0 & 0 & 0 & 0 & 0 & 0 & 0 & 0.185 & 0.076 & 0.176 & 0.192 & 0 & 0 & 0 \\
\hline ARC & 0 & 0 & 0 & 0 & 0 & 0 & 0 & 0.19 & 0.195 & 0.079 & 0.209 & 0 & 0 & 0 \\
\hline CIB & 0 & 0 & 0 & 0 & 0 & 0 & 0 & 0.192 & 0.22 & 0.194 & 0.086 & 0 & 0 & 0 \\
\hline EPD & 0 & 0 & 0 & 0 & 0 & 0 & 0 & 0 & 0 & 0 & 0 & 0.058 & 0.212 & 0.196 \\
\hline EST & 0 & 0 & 0 & 0 & 0 & 0 & 0 & 0 & 0 & 0 & 0 & 0.15 & 0.053 & 0.174 \\
\hline TCE & 0 & 0 & 0 & 0 & 0 & 0 & 0 & 0 & 0 & 0 & 0 & 0.204 & 0.202 & 0.061 \\
\hline
\end{tabular}

Table 4. Total-Relationship Matrix 
Dakare et al.

Appendix- $V$

\begin{tabular}{cccrr}
\hline & $\mathbf{R}$ & $\mathbf{C}$ & $\mathbf{R}+\mathbf{C}$ & $\mathbf{R}-\mathbf{C}$ \\
\hline MC & 5.034 & 4.219 & 9.253 & 0.815 \\
KSE & 4.675 & 3.973 & 8.648 & 0.702 \\
FC & 5.275 & 4.751 & 10.026 & 0.524 \\
EOS & 4.735 & 4.317 & 9.052 & 0.418 \\
COR & 3.811 & 5.198 & 9.009 & -1.387 \\
SP & 3.156 & 5.105 & 8.261 & -1.949 \\
ACE & 4.693 & 3.816 & 8.509 & 0.877 \\
MK & 0.737 & 0.651 & 1.388 & 0.086 \\
CDC & 0.629 & 0.694 & 1.323 & -0.065 \\
ARC & 0.673 & 0.671 & 1.344 & 0.002 \\
CIB & 0.692 & 0.715 & 1.407 & -0.023 \\
EPD & 0.466 & 0.412 & 0.878 & 0.054 \\
EST & 0.377 & 0.467 & 0.844 & -0.09 \\
TCE & 0.467 & 0.431 & 0.898 & 0.036 \\
\hline Sourc: Authors' $0 w n$
\end{tabular}

Table 5. Cause-and-Effect Relationship Matrix 